WIDER Working Paper 2016/5

\title{
Industry in Tanzania
}

Performance, prospects, and public policy

John Page*

March 2016 
Abstract: Tanzania ranks among the leading stars of the 'African growth miracle', but a sector that has been largely absent from the Tanzania success story is industry. Although growth of manufacturing has outpaced economic growth over the past decade, relative to international norms and its ambitious plans to achieve middle-income status Tanzania suffers from a 'manufacturing deficit' at its current level of per capita income. The paper discusses a number of policy initiatives that should be undertaken to strengthen the industrial sector's recent dynamism, including strengthening Special Economic Zones, improving trade logistics, and reforming Micro and Small Enterprise programmes.

Keywords: Tanzania, industrial development, industrial policy, structural transformation JEL classification: $\mathrm{O} 14, \mathrm{O} 25, \mathrm{O} 55$

Acknowledgements: at the end of the paper.

* The Brookings Institution, Washington, DC, United States, jmpagejr@gmail.com.

This study has been prepared within the UNU-WIDER project 'Jobs, poverty and structural change in Africa' as part of UNU-WIDER's collaboration with Policy Research for Development (REPOA) on socio-economic transformation.

Copyright (C) UNU-WIDER 2016

Information and requests: publications@wider.unu.edu

ISSN 1798-7237 ISBN 978-92-9256-048-5 https://doi.org/10.35188/UNU-WIDER/2016/048-5

Typescript prepared by Anna-Mari Vesterinen.

UNU-WIDER acknowledges specific programme contribution from Policy Research for Development (REPOA) for a series of studies on socio-economic transformation and core financial support to its work programme for the governments of Denmark, Finland, Sweden, and the United Kingdom

The United Nations University World Institute for Development Economics Research provides economic analysis and policy advice with the aim of promoting sustainable and equitable development. The Institute began operations in 1985 in Helsinki, Finland, as the first research and training centre of the United Nations University. Today it is a unique blend of think tank, research institute, and UN agency - providing a range of services from policy advice to governments as well as freely available original research.

Katajanokanlaituri 6 B, 00160 Helsinki, Finland

The views expressed in this paper are those of the author(s), and do not necessarily reflect the views of the Institute or the United Nations University, nor the programme/project donors. 
Tanzania ranks among the leading stars of the 'African growth miracle'. Since the turn of the century it has averaged 5-7 per cent annual growth of gross domestic product (GDP), an impressive track record but one that comes with a number of cautionary warnings. First, the increase in GDP is less striking when adjusted to take into account rapid population growth. Per capita GDP growth has averaged just 2.5-3.5 per cent per year over the same period, slightly above the average per capita growth rate for sub-Saharan Africa as a whole. Second, the Tanzanian economy has added fewer 'good' jobs-those paying decent wages and offering some security of employment - than would be expected from its overall growth performance. Third, Tanzania's rapid economic growth has not translated into correspondingly rapid reductions in poverty.

A sector that has been largely absent from the Tanzania success story is industry. Industryincluding manufacturing, agro-industry, and tradable services-is a high productivity sector that has the potential to absorb large numbers of modestly skilled workers, contribute to accelerated poverty reduction, and diversify the economy. This paper addresses the role that industry can play in Tanzania's economic future. The idea that Tanzania should industrialize is certainly not new. The country's post-independence leadership viewed industry as an important means to transform Tanzanian society and reduce its dependence on the former colonial powers. However, most of the industries established in the post-independence period failed to survive, leading to a sharp reduction in the role of industry in the economy and a long period of faltering industrial growth. The share of manufacturing in GDP fell from more than 22 per cent in 1975 to about 10 per cent in 1990. Now, industry may be turning a corner. In contrast with the previous two decades there is some evidence of new dynamism.

The remainder of the paper is organized as follows. The next section surveys a number of structural characteristics of the Tanzanian economy. It presents evidence that relative to international norms and its ambitious plans to achieve middle-income status Tanzania suffers from a 'manufacturing deficit' at its current level of per capita income. Section 3 makes the case for industrial development based on three pressing needs: boosting job creation, accelerating poverty reduction, and sustaining growth. Section 4 presents evidence on the current state of industrial development. There is some good news here; growth of manufacturing has outpaced economic growth over the past decade. Section 5 discusses a number of policy initiatives that should be undertaken to strengthen the industrial sector's recent dynamism and accelerate industrial growth. Section 6 concludes.

\section{Structural change and the manufacturing deficit}

The goal of Tanzania's Vision 2025 is to move to middle-income status. In the course of that transition Tanzania's economy is likely to undergo profound changes in its economic structure (Kuznets 1955; Chenery 1986). In other economies industry has been the key driver of such structural change. The East Asian miracle is an industrial success story. In the last thirty years Asia has become 'the world's factory'. Between 1960 and 2010 the movement of workers from lower to higher productivity sectors across Asia-mainly into manufacturing-nearly doubled the economy-wide rate of growth of output per worker (de Vries et al. 2013). Industry has played a much smaller role in Tanzania's structural transformation. 


\subsection{Structural change in Tanzania}

Like most of Africa, Tanzania has only recently begun to experience significant structural change (McMillan et al. 2013). Beginning in the mid-1970s and lasting until late in the 1990s, agriculture's share of the Tanzanian economy increased and the economic weight of higher productivity sectors declined. As a result, structural change in Tanzania was growth reducing; an increasing share of output and the labour force was moving into sectors with productivity levels below the average for the economy as a whole (de Vries et al. 2013). Since around 2000, the pace of structural change has picked up and the pattern has become growth enhancing. The share of the labour force engaged in agriculture declined from 86.1 per cent to 73.4 per cent between 2000 and 2010, as workers moved into higher productivity sectors.

Unlike the industrial transformation that took place in East Asia, however, the bulk of workers leaving agriculture in Tanzania have moved into the services sector (Table 1). Between 1990 and 2010 the share of the total labour force in services rose from 11.3 to 20.6 per cent, and the share of retail and distribution services workers in total employment nearly doubled from 6.2 to 12.0 per cent. Although the average productivity in services is higher than in agriculture, the growth of employment in services has not been matched by output growth, suggesting that the marginal productivity of workers moving into the sector is low.

Manufacturing has also begun to absorb an increasing share of the labour force. Between 1990 and 2010, the share of the labour force engaged in manufacturing increased from 1.4 to 2.7 per cent while the share of manufacturing in GDP increased modestly from 10.0 to 10.6 per cent. Despite the recent growth in manufacturing output and employment, Tanzania still has a very long way to go before it conforms to the global cross-country relationship between industrialization and income per capita. Tanzania is among a group of African growth miracle countries including Ghana, Kenya, Uganda, and Rwanda all of which have levels of manufacturing activity substantially below the share of GDP predicted on the basis of their per capita income (Dinh et al. 2012).

\subsection{Benchmarking Tanzania's manufacturing deficit}

In 2010 Tanzania had a per capita gross national income of about US $\$ 1,490$ at purchasing power parity. This placed it among the ranks of low-income countries transitioning to lower middleincome status. Table 2 compares Tanzania's employment structure with the distribution of employment of four 'benchmark' economies corresponding to the international classification of countries by per capita income level. The benchmarks show the structural characteristics of economies-mainly in Asia-that have made or are making the transition to middle-income status. ${ }^{1}$ The labour share values for the benchmarks are the simple averages of the labour shares of the relevant countries at the time their per capita incomes were first equal to the income classification in the Table.

The most striking feature of Table 2 is how far the structure of the Tanzanian economy is from any of the benchmarks. Relative to other countries at its level of per capita income Tanzania has had little structural transformation. About three-fourths of Tanzanian workers continue to be employed in agriculture. This is similar to the agriculture share of the least developed economies and high compared with the employment shares of around 60 per cent found in the low- and

\footnotetext{
${ }^{1}$ The benchmark countries are: Bangladesh, Cambodia, Chile, China, India, Indonesia, Korea, Malaysia, Philippines, Thailand, and Viet Nam. The country-year composition of each benchmark is given in the notes to the table.
} 
lower middle-income country benchmarks. The manufacturing deficit is particularly significant. Only 2.7 per cent of Tanzanian workers were employed in manufacturing in 2010, compared with 12-14 per cent of workers in the low- and lower middle-income benchmark economies. Given Tanzania's aspirations to achieve middle-income status over the next ten years the size of the manufacturing deficit with middle-income countries is even more daunting. The share of the labour force in manufacturing in the upper middle-income benchmark is ten times the manufacturing labour force share in Tanzania.

\section{Why industry matters for Tanzania}

Whether seen from the perspective of its current level of development or its level of aspiration, Tanzania seems to have far too little industry. But does this really matter? Recent discoveries of significant gas reserves combined with other mineral resources suggest that Tanzania's long-term economic prospects are bright. Natural resource abundance, however, carries new risks. The extensive literature on the 'resource curse' points to some, but perhaps the greatest risk to Tanzania is that a resource boom may reinforce the current disconnect between growth, job creation, and poverty reduction. ${ }^{2}$ Gas fields and mines create relatively few jobs, and they have few linkages with the domestic economy. Industry can play a complementary role to natural resources through job creation, poverty reduction, and diversification of the economy.

\subsection{Jobs}

Tanzania has a young and rapidly growing population. Approximately 800,000 new workers enter the domestic labour market every year. The economy, however, is not creating that number of 'good' jobs-jobs that pay living wages, give some security of employment, and offer prospects to develop skills (World Bank 2014a). In fact Tanzania's performance in job creation has been among the most disappointing of the region's growth miracle economies. Figure 1 shows the elasticity of formal sector employment with respect to economy-wide growth for a range of African countries. In general the region's fastest growing economies-Ethiopia, Rwanda, and Uganda among them-have the lowest responsiveness of formal employment to growth (Page and Shimeles 2015), but Tanzania stands out, even among this group for its very low employment elasticity of growth.

As the supply of labour seeking non-farm employment has outpaced demand in the wage sector, many labour force participants have been left with no choice but to create their own jobs (Kweka and Fox 2011). Today five million non-farm businesses operate in Tanzania. This is one of the highest rates of business formation in the world (one for every four people), four times higher than in the United States and ten times higher than in France (World Bank 2014a). The vast majority of these enterprises are in the household sector. Between 2000/01 and 2006 employment in the household enterprise sector grew by 13 per cent, exceeding the overall change in the labour force and the growth of wage employment. More than two-thirds of these household enterprises in urban areas were formed because of lack of any other job opportunities (Kweka and Fox 2011).

\footnotetext{
${ }^{2}$ For a comprehensive survey on the resource curse literature see van der Ploeg (2011).
} 


\subsection{Poverty}

Growth in per capita income has reduced poverty in Tanzania at a slower rate than in other parts of the world. Using the international income poverty standard of US $\$ 1.25$ per day, the share of the poor in Tanzania's population fell from 85 per cent in 2001 to 68 per cent in $2007 .{ }^{3}$ Given Tanzania's fast growth, this rate of progress compares unfavourably to other low-income countries. ${ }^{4}$ Tanzania's growth elasticity of extreme poverty is less than 0.5 , which is quite low compared to estimates of 1.6 to 2.5 found in the cross-country literature (Fosu 2011).

Tanzania's slow pace of structural change has contributed to its slow pace of poverty reduction. One way to assess the extent to which structural change has had an impact on poverty is to undertake a set of poverty using sector specific poverty headcount data and a counterfactual distribution of employment based on the structural characteristics of the low-income benchmark economies defined in Section 2. In effect this is asking the question: what would the poverty outcome in Tanzania have been, if structural change had been more in line with the observed experience of the benchmark economies?

Sector specific poverty headcounts are available from household survey data for a number of African countries, including Tanzania (Table 3). The poverty data are reported at the level of three broad sectors-agriculture, industry, and services. In general, African economies have the highest poverty incidence in agriculture and the lowest in services. Tanzania differs somewhat: its poverty headcount is lowest in industry, 29 per cent of households, and the poverty incidence in agriculture is about double that in the other two sectors. Table 4 reports the results of the simulations. A shift of labour out of agriculture into industry and services in line with that experienced by the benchmark economies would have reduced the poverty headcount from 62.6 to 55.2 per cent. This is among the largest simulated reductions in poverty in the Africa sample.

\subsection{Sustaining growth}

Industry can also play a role in establishing the basis for sustained growth in an increasingly resource dependent economy. Unless natural gas and other resources become so abundant that they will dominate the economy indefinitely, the ability to sustain growth after the resources are depleted is a major concern. In addition to its contributions to job creation and poverty reduction, industry has a number of characteristics that make it an attractive sector on which to build a basis for sustained growth. This is because there is mounting evidence that there is 'something special' about industry in the early stages of economic development.

One special characteristic of industry is called 'unconditional convergence'. Modern manufacturing industries converge to global best practice productivity levels regardless of geographical disadvantages, poor institutions, or bad policies-a characteristic they do not share with agriculture or traditional services (Rodrik 2013). This opens up two channels for sustained economy-wide growth. The first is productivity growth within manufacturing itself. The second is structural change into manufacturing. Because the manufacturing sector has the potential to converge unconditionally to high levels of productivity, a shift in employment out of agriculture into manufacturing - the pattern of structural change seen in Asia-can be strongly growth

\footnotetext{
${ }^{3}$ For a discussion of the differences in measures of poverty in Tanzania see Atkinson and Lugo (2010).

4 The low responsiveness of poverty to growth is common to a number of other African growth miracle economies. See Page (2014).
} 
enhancing, but its impact depends crucially on the size of the modern manufacturing sector and its rate of growth, in short on the pace of industrialization (Rodrik 2014).

There is also evidence that within manufacturing more diverse and sophisticated production and export structures increase the chances for sustained growth. Countries that produce and export more sophisticated products - those that are primarily manufactured by countries at higher income levels - tend to grow faster (Hausmann et al. 2006; UNIDO 2009). ${ }^{5}$ The link between manufacturing sophistication and growth is not fully understood, but it is likely to reflect the impact of higher 'firm capabilities' on productivity. ${ }^{6}$ The ability of firms in lower income economies to produce, and especially, to export goods mainly produced in higher income countries indicates that they have mastered both the technology and the management practices, including quality control and value chain management, required to be competitive with firms in advanced economies. These are 'high capability' firms and economies with large numbers of such firms have a stronger base for productivity change and long-run growth (Sutton 2012).

\section{$4 \quad$ Recent developments in industry}

Tanzania has a long way to go with respect to industrialization, but there are signs that it may be turning a corner. In contrast with most African economies the share of total output and employment of Tanzanian industry is increasing, albeit from an extraordinarily low base. Growth in formal manufacturing has been above the average rate of economic growth since 2000, and the number of manufacturing firms more than doubled between 2005 and 2010 (Kweka and Ugarte 2013). Getting a clear picture of the current state of industry in Tanzania is not easy, however. The manufacturing sector consists of at least three distinct segments. At the top are a relatively small number of medium- and large-scale firms. These firms generally employ more than 50 workers, are registered with the government, and provide employment contracts which conform to labour legislation. A second tier consists of registered micro and small enterprises (MSEs) in manufacturing, defined by the Ministry of Industry and Trade as those with fewer than 50 employees. These enterprises differ yet again from the third segment, 'household enterprises' that engage in manufacturing. Household enterprises typically are very small, are not registered, and do not have paid employees. Often their owners are self-employed due to failure to find a wage paying job (Kweka and Fox 2011).

Differences among the three categories in terms of the number of firms are stunning. The Annual Survey of Industrial Production (ASIP) collects detailed information on all registered industrial establishments with at least ten employees in mining, manufacturing, electricity, and water. It contains 729 firms of which 59.2 per cent are small, 14.5 per cent are medium, and 26.3 per cent are large-scale enterprises. In 2010 the Central Register of Establishments (CRE) contained approximately 6,800 manufacturing enterprises. Of these approximately 30 per cent were micro enterprises and 65 per cent were small enterprises (Kweka and Urgarte 2013). The ASIP includes about 432 small manufacturing firms (5-49 workers) while the CRE counts 6,460 registered micro and small manufacturing firms. The Tanzania National Panel Household Survey

\footnotetext{
${ }^{5}$ There is of course a problem of identification. Hausmann and his colleagues argue that their econometric evidence points to the relationship running from greater sophistication to growth, and that the relationship is robust to a number of specifications and treatments for two-way causality. UNIDO uses a different approach to address the problem and arrives at similar results.

${ }^{6}$ Firm capabilities are the knowledge and working practices embodied in the managers and workers who make up an enterprise.
} 
(NPS) reports that about 18 per cent of Tanzania's approximately five million non-farm household enterprises are in engaged in manufacturing, mainly making beverages, apparel, and furniture. ${ }^{7}$ These are tiny firms consisting of a single entrepreneur, perhaps working with unpaid workers who are likely to be family members (Kweka and Fox 2011).

\subsection{Formal manufacturing}

Formal manufacturing has grown significantly in the last decade. Between 2000 and 2010, manufacturing value added (MVA) more than doubled in real terms from US\$894 million to US $\$ 1,992$ million (UNIDO 2012). Since 2010 growth of the manufacturing sector has continued to outpace overall GDP growth, but it has lagged growth in a number of services sectors. Beginning from a very small base in 2000, per capita manufacturing value added grew at 5 per cent per year between 2000 and 2010 to reach US $\$ 44$, exceeding the Africa-wide average of US $\$ 35$ but still below the average for all low-income countries of US $\$ 61$ (Table 5).

Agro-processing is the dominant manufacturing sub-sector. The 287 agro-processing companies in the ASIP account for 55 per cent of total formal manufacturing output and 65 per cent of total employment. More than 80 per cent of agro-processing companies are small and serve the domestic market. Manufacture of furniture (13 per cent), non-metallic mineral products (11 per cent), tobacco ( 7 per cent), and textiles ( 5 per cent) round out the list of other major manufacturing activities in terms of output.

Textiles and apparel, and leather as well as leather products experienced sharp declines in the 1990s and have not recovered. Although Tanzania is a major cotton producer, the textiles and apparel sector is small. Tanzania processes only about 20 per cent of its own cotton after ginning, and it exports the rest. The local processing industry produces few, largely low-quality products and depends heavily on imports (Dinh and Monga 2013). Tanzania has the third largest livestock population in Africa, but its production of leather and leather products is very limited. About three-quarters of locally produced raw hides and skins are exported, and 95 per cent of the remainder is exported after limited processing. Only 13 small firms are active in the final products segment (8 produce leather footwear). They employ an estimated 200-300 people and mainly serve the domestic market.

\section{Sunrise industries}

As part of a project implemented by the African Development Bank, the Brookings Institution, and UNU-WIDER, REPOA undertook a purposive survey of 50 emerging industrial enterprises in Tanzania in 2012 (Wangwe et al. 2014). Firms were selected based on three criteria: introduction of new products, rapid growth of market share, and export growth. These are the manufacturing sector's 'sunrise industries'. Between 2010 and 2012, the output of the firms surveyed grew by an average of 48.8 per cent. The most successful firms in terms of growth were in food processing, machinery and equipment, textiles, and basic metals. In each of these sectors the firms interviewed had increases in output of more than 40 per cent per year. Paper, electrical equipment, and manufacture of basic metals had the highest rates of employment growth among new companies.

\footnotetext{
${ }^{7}$ Retail trade is by far the most important household activity representing 55 per cent of all household enterprises. Food and beverage services and other personal services account for 10 and 5 per cent respectively.
} 
The surveys revealed a number of characteristics of dynamic firms. About 80 per cent of the firms interviewed hired in professional managers and cited 'quality management' as an important element in the firm's success. Over 90 per cent indicated that they had significantly adapted sales and marketing strategies in the last three years, and about a third had introduced new products. Half of the firms surveyed reported that they undertook in-house research and development activities. The great majority of firms were highly import-dependent. On average, almost 70 per cent of intermediate inputs were imported and a third of the firms interviewed relied exclusively on imported inputs.

\section{Manufacturing sophistication}

Manufacturing is concentrated in a few low-tech sectors (UNIDO 2012). The share of medium and high-technology products in total manufacturing output was about 12 per cent in 2011, below the Africa-wide average. Tanzania's industrial sector has become less sophisticated-in the sense discussed above-over time. Figure 2 traces production (and export) sophistication for Tanzania and a sample of fast growing low-income countries over the period from 1975 to $2005 .^{8}$ Because the measure of sophistication is itself related to each country's level of per capita income, there is an in built positive correlation between income level and the measure of production and export sophistication. Figure 2 attempts to deal with this in two ways. The first is to compare Tanzania with low-income countries only. The second is to express the measure of sophistication as the deviation from its predicted value, given per capita income in the period of observation. The central tenant of 'what you make matters' is that on average countries that are positive outliers with respect to the income-sophistication relationship should grow faster in the long run.

Production sophistication in Tanzania was higher in 1975 than its predicted value but declined steadily up to 2000 before recovering somewhat in 2005. Fast growing low-income countries on average had an overall increase in production sophistication over the same period. They began with a less sophisticated average production structure relative to their income levels than Tanzania but had overtaken it by 1985. By 2005 the average manufacturing sector of the lowincome fast-growers was substantially more sophisticated than in Tanzania.

\section{Competition}

Despite trade liberalization and increased imports, large enterprises in Tanzanian manufacturing appear to face weaker competitive pressure than those in other East African countries. Most manufacturing sub-sectors in Tanzania have high concentration relative to international comparators, and in many industries the top three or four firms account for more than 50 per cent of domestic production (Yoshino et al. 2013). About 24 per cent of large firms in Tanzania indicated in the 2006 Enterprise Survey conducted by the World Bank that there were no new competitors in the markets in which they operated.

Concentration is particularly significant in capital intensive, higher technology sectors such as machinery and equipment, motor vehicles and electrical machinery and apparatus, but such lower technology sectors as leather and leather products, apparel, textiles, and wood products show levels of concentration that indicate limited scope for competition. Lack of competitive pressure may be partly responsible for the decline in manufacturing sophistication. The survey

\footnotetext{
8 The sample and the method of estimating production and export sophistication are described in the 2009 UNIDO Industrial Development Report.
} 
data from 2006 show that Tanzania firms facing less competition made fewer investments in machinery and were less active in introducing new products and new processes in their industrial activities (Yoshino et al. 2013).

\subsection{Dynamics of the 'in between' sector}

The recent decline in the employment share in agriculture in Tanzania has been accompanied by a proliferation of MSEs. Margaret McMillan (2014) argues that there is a great heterogeneity among these firms with many looking more like modern small enterprises than traditional, informal sector firms. Citing Arthur Lewis (1979), she suggests that these 'in between' firms have the potential to contribute to job creation and growth. Unfortunately, while the government of Tanzania recently finished its first nationally representative survey of micro, small and medium size firms (Ministry of Industry and Trade 2012) the data have not yet been comprehensively analysed. What we know about the 'in between sector' must be inferred from the successive rounds of the Central Register of Enterprises.

Between 2005 and 2010 the number of MSEs registered in the CRE more than doubled. Growth of manufacturing establishments kept pace with overall enterprise growth, keeping the manufacturing sector's share of establishments constant. ' Virtually all of the increase in manufacturing establishments between 2005 and 2010 was due to growth in the number of small enterprises (employing 5-49 workers). Declines were recorded in the shares of micro (employing 1-4 workers), medium (50-99), and large (more than 100) manufacturing establishments (Kweka and Urgarte 2013).

A comparison of the 2009 and 2010 registers reveals significant 'churning' through firm entry and exit. MSEs accounted for the vast majority of exits, around 96 per cent of all exiting firms. Manufacturing exhibited one of the higher firm survival rates. About 15 per cent of the stock of firms in manufacturing in 2009 exited in 2010. This contrasted quite sharply with exit rates in market services that ranged from 33 to 65 per cent (Kweka and Urgate 2013). Growth among surviving firms between 2009 and 2010 was not impressive, perhaps in part due to the very short time interval between the two waves. Micro and small manufacturing firms were more likely to grow than those in a number of other sectors.

Overall, the CRE data paint a picture of growth in manufacturing that is due primarily to the entry of new micro and small firms. This may signal that growth of McMillan's (2014) in between sector is an important part of Tanzania's new industrialization story, but without more comprehensive firm-level data it is difficult to assess its contribution to the economy. Views on the potential of informal, small enterprises differ markedly. One prevalent view is that: informality undermines private investment and productivity growth (Kenyon and Kapaz 2005). An alternative perspective suggests that while many micro and small firms are 'survival firms' they also include enterprises that are equally or even more productive than those in the formal sector (Günther and Launov 2012; Jones and Tarp 2015).

The relative productivity of small and large firms is the key to resolving the debate. Without detailed firm-level data on the vast number of MSEs excluded from the ASIP it is impossible to answer the question definitively. Africa-wide data provide some insights, however. Page and Söderbom (2015) use data on nine African countries from the World Bank Enterprise Surveys to

\footnotetext{
9 Information and communication (ICT), finance and real estate, other activities, electricity and water, and professional services were the fastest growing sectors.
} 
investigate the size-productivity relationship. They find that there is a strong positive relationship between value added per employee and firm size (Figure 3). ${ }^{10}$ The size-productivity differential is very pronounced, even among relatively small firms. Firms with 30 employees have, on average, twice as much value added per worker as firms with five employees. Value added per worker in African firms with 100 employees is more than three times higher than that in firms with five employees, and in firms with 200 employees it is 3.5 times higher. In other words, the average worker in a 200 worker firm produces as much value added in 17 minutes as the average worker in a five worker enterprise does in an hour.

Results of analysis of firm-level data from the World Bank (2006) Enterprise Survey) and the Annual Survey of Industries tell a broadly similar story. Using information for 607 firms surveyed by the Annual Survey of Industrial Production of 2008, Kweka and Urgarte (2013) identified characteristics associated with firm-level productivity, measured in terms of both output per worker and value added per worker. Small firms were found to have significantly lower productivity levels than medium and large firms, which were statistically indistinguishable from each other. Firms involved in food processing, textiles, and furniture-the sectors into which small manufacturing enterprises were moving between 2005 and 2010-were associated with lower levels of productivity.

A somewhat more positive message is contained in Figure 4. It shows the distributions of output per worker for small, medium and large firms from the World Bank (2006) Enterprise Survey. While small firms are more concentrated at lower productivity levels, the right hand tail of the distribution for small enterprises is of interest. There are apparently substantial numbers of small scale firms in Tanzania that have productivity levels equal to those of medium and large scale enterprises. These are likely to be the in between firms with the potential to survive and grow. The small firms in the Enterprise Survey, however, are a tiny subset of the MSEs in manufacturing in Tanzania.

\subsection{Industrial exports}

Tanzania has had the most rapid growth of manufactured exports among its East African neighbours (UNIDO 2012). During the second half of the 2000s, the number of new Tanzanian exporters grew by 7.7 per cent per year (Cadot, Regolo, and Yoshino 2012). Between 2000 and 2010 manufactured exports increased from US $\$ 129$ million to US $\$ 1,904$ million (a rate of 31 per cent per annum), and the share of manufactures in total exports increased from 37 to 42.5 per cent (Table 5). The bulk of this increase took place in the second half of the decade when manufactured exports grew at 45 per cent per year. Manufactured exports per capita increased from US $\$ 3$ in 2000 to US $\$ 43$ in 2010, exceeding the Africa-wide average (excluding South Africa) of US $\$ 40$, but still less than the average for all low-income countries. Exports of services have grown rapidly as well. Transportation services grew tenfold between 2002 and 2012, and computer and information services exports grew by nine times. Tourism was the nation's leading export for most of the decade.

\section{Sources of export dynamism}

Growth of existing exports of manufactured products to current destinations (intensive growth) has contributed little to overall manufactured export growth (Table 6). Rather, the sale of new

\footnotetext{
${ }^{10}$ An important reason why small African firms have much lower labour productivity than large African firms is that capital intensity varies strongly with firm size.
} 
products to traditional destinations and finding new customers for traditional products (extensive growth) have accounted for 95 per cent of the net growth in manufactured exports between 2000 and 2010. Regional exports in East Africa accounted about half of the growth in the extensive margin and exports destined to Asian countries accounted for slightly more than 30 per cent (Yoshino et al. 2013). Chemical products, such as fertilizer, have been the leading manufactured products entering new markets.

While the number of Tanzanian exporters is growing, their exit rate is also high. The survival rate of Tanzanian exporters fell from 45 per cent in 2003 to 29 per cent in 2008 (Yoshino et al. 2013). This is one of the lowest exporter survival rates of a sample of lower-income countries in the World Bank (2015a) Exporter Dynamics Database. The number of active export firms has stalled at a lower level (about 50 exporting firms per million inhabitants) than in Rwanda and Uganda, (Cadot, Regolo, and Yoshino 2012). Between 2003 and 2009, only 17 firms (the top 1 per cent) accounted for 60 per cent of total exports. The top 25 per cent of exporters (425 firms) accounted for 99 per cent of total exports

The factors that drive export success in Tanzania are not surprising and reflect the characteristics of exporters from most low-income countries. Yoshino et al. (2013), using data from the World Bank Enterprise Surveys, estimated both the probability of Tanzanian firms entering export markets (export propensity) and the share of total output devoted to exports (export intensity) for medium and large scale Tanzanian exporters. They find that the firm characteristics that influence export propensity include: (i) size; (ii) ownership; (iii) labour productivity; (iv) use of imported inputs; and (v) location in an industrial zone. The results for export intensity are very similar.

The decision to become an exporter is mainly driven by the firm's size, productivity, and ownership. A Tanzanian firm with more than 100 workers is 82 per cent more likely to become a global exporter than a medium sized firm. Size matters because high volumes reduce transaction and transport costs. These costs are mostly fixed and can therefore be better absorbed by large firms. The strong influence of productivity on export propensity reflects the stylized fact that exporters must be productive to be competitive in global markets, but it may also reflect the presence of 'learning by exporting'. ${ }^{11}$ Foreign-owned firms in Tanzania are more likely to export than domestic firms. Given that foreign ownership is often associated with higher levels of firm capabilities (Sutton 2012), there may be a close correlation between ownership and initial productivity that influences the export decision. The use of imported inputs may reflect both the role of imported intermediates in raising product quality and the growing significance of 'trade in tasks' - the geographical dispersion of stages of the value chain-in Tanzania's export bundle.

\section{Export sophistication}

Tanzania's manufactured export structure is relatively unsophisticated. The share of mediumand high-tech exports in total manufactured exports was only 16.7 per cent in 2010, below the regional average of 21 per cent (Table 5). Nearly half of the country's manufactured exports in 2010 were resource-based products (mostly base and precious metal ore). The measure of export sophistication described in Section 3 is shown in Figure 2. Tanzania's manufactured exports are less sophisticated than expected for its level of per capita income. After an early increase, export

\footnotetext{
${ }^{11}$ For a literature survey see Harrison and Rodriguez-Claire (2009). See the forthcoming Special Issue of the Journal of African Economies for recent evidence on the presence of learning by exporting in Africa and other low-income countries.
} 
sophistication fell continuously relative to predicted values from 1985 to 2005, finishing the period as a negative outlier. In fast growing low-income countries, despite some variations, export sophistication was consistently high relative to predicted values over the same period. It also generally exceeded production sophistication, indicating that more sophisticated products made up a higher share of the export basket than the overall product structure. By 2005 in contrast with the low-income fast-growers Tanzania's manufacturing sector as a whole had become more sophisticated than its manufactured exports.

Using a separately estimated set of export sophistication measures for 2010, Regolo (2012) finds that manufactured exports from Tanzania are least sophisticated at the intensive margin (growth in traditional products exported to existing markets). ${ }^{12}$ The sophistication of existing products entering new markets and particularly of new products entering existing destinations (extensive growth) is substantially greater. While this suggests that extensive export growth may have contributed to rising export sophistication, the sophistication of the export basket of new products to new markets is low, and the average sophistication of exports that have exited traditional destinations is substantially higher than the basket of exports in traditional markets.

\section{$5 \quad$ Policies for industrial growth}

Since the Sustainable Industrial Development Policy for Tanzania (SIDP 1996-2020) was adopted in 1996, industrialization has received more attention in the national development discussion than at any point since independence. In 1999 Tanzania's Development Vision 2025 set the goal of achieving 'transformation from a weather and market dependent agricultural economy to a selfsustaining semi-industrialized economy.' ${ }^{13}$ The Tanzania Mini-Tiger Plan 2020 was introduced in 2005 in an effort to fast-track the implementation of the Tanzania Development Vision by replicating the East Asian model of export-led industrialization. In June 2010 an Integrated Industrial Development Strategy 2025 (IIDS) was adopted with a growth target for manufacturing value added of 15 per cent per year.

The results in terms of industrial development have failed to keep pace with the rhetoric. This section describes some of the policies needed to realize Tanzania's ambitious industrial development goals. It does not pretend to be comprehensive. Rather, it is intended to provoke debate by highlighting two areas - creating an export push and strengthening the performance of the in between sector-where new thinking and decisive government action are needed.

\subsection{Creating an export push}

Sustained and more rapid export growth of the type envisaged in the Tanzania Mini-Tiger Plan 2020 will need an 'export push'-a coordinated set of public investments, policy reforms, and institutional changes focused on increasing the share of industrial exports from both manufacturing and tradable services in GDP. The public actions needed to achieve an export push range from maintaining a competitive real exchange rate to public investments in traderelated infrastructure and skills to institutional and regulatory reforms. ${ }^{14} \mathrm{~A}$ full discussion of the changes needed in Tanzania to achieve an effective export push would require a paper in itself.

\footnotetext{
12 The estimates are constructed using the same methodology and are thus comparable.

${ }^{13}$ United Republic of Tanzania (1999).

14 See Page (2012).
} 
Here, the focus is on only two key areas-special economic zones (SEZs) and trade logistics. Both are cases of policy and institutional innovations that have been implemented in other newly industrializing countries, but which perform less well in Tanzania. Both represent serious constraints to more rapid export growth and both have well codified 'best practice'. Thus, they are a good place to begin.

\section{Strengthening special economic zones}

Many newly industrializing countries-most spectacularly China-have established SEZs as a key component of an export-oriented industrialization strategy. One objective of most governments has been to establish a 'free trade regime for exporters' through mechanisms to eliminate or rebate tariffs on intermediate and capital inputs used in export production. Beyond the free trade regime for exporters, the 'new economic geography' has helped to deepen our understanding of why SEZs can promote industrialization. Industrial agglomeration raises firmlevel productivity, but it also sets up a collective action problem. Because a critical mass of firms is needed to realize productivity gains in a new industrial location, no single firm has the incentive to locate in a new area in the absence of others. This favours locations where industry is already present and makes it difficult to attract new investors to sparse industrial landscapes (UNIDO 2009).

There is some evidence that governments can foster industrial clusters by concentrating investments in high quality institutions, social services, and infrastructure in a limited geographical area, such as a SEZ (UNIDO 2009; Farole 2011). Thus, export-oriented SEZs, if they are well-developed and well-managed, can be an effective tool in attracting global investors in manufacturing. One of the key success factors in the industrialization of Cambodia and Viet Nam was the ability to attract a large number of Asian regional investors to relocate export production from higher cost economies in East Asia to SEZs in both countries. Tunisia was able to attract a similar critical mass of European investors into its 'off shore' sector.

Tanzania is a relative latecomer to the use of SEZs. The government established the Export Processing Zones Authority (EPZA) in 2006. The Authority has created both industrial parks, where investors locate their operations together in a designated zone, and stand-alone EPZs, that allow individual companies to be licensed as free zones regardless of where they are located. In 2006 the government also launched a SEZs programme as part of the Mini-Tiger Plan. The programme envisaged a wide range of SEZ modalities: EPZs, free ports, free trade zones, specialized industrial clusters, agricultural free zones, industrial parks for SMEs, microenterprise manufacturing parks, and information and communication technology parks. The Economic Zones Law of 2011 unified the EPZ and SEZ programmes by making EPZs a part of the SEZ programme and gave oversight authority for both programmes to the EPZA.

Not surprisingly, the long delays in clarifying the institutional and regulatory regime have resulted in a slow start for SEZs in Tanzania. The government has allocated 13 sites for SEZs, but only seven have been licensed, and only one of these seven, the Benjamin William Mkapa Special Economic Zone in Dar es Salaam, is operated as an SEZ. A second SEZ under development in Bagamoyo is not yet operational (World Bank 2013b). There are also 20 stand-alone plant-level EPZs. In total Tanzania's SEZs contain about 40 firms, employing around 10,000 people. By way of comparison SEZs in the Dominican Republic contain more than 550 firms; Honduras has nearly 350 firms; and Bangladesh, 300. Viet Nam has 3,500 firms in its export processing and industrial zones (Farole 2011). 
The SEZ programme has had a limited impact on exports. Firms in Tanzania's EPZs have the lowest export orientation among a sample of African countries studied by the World Bank (Farole 2011). Most exporters operating in EPZs target the regional African market. Econometric analysis based on the World Bank 2006 Enterprise Survey shows that location in industrial zones is positively correlated with both the probability a firm will export and how much it exports. Relative to other East African countries, however, this effect is significantly smaller in Tanzania (Yoshino et al. 2013). Being based in an industrial zone in Tanzania does less to enhance export performance than in other East African Community (EAC) countries, suggesting that to date SEZs have been largely ineffective at promoting exports, particularly to non-regional destinations. Perhaps not surprisingly, nearly 70 per cent of firms located in Tanzania's SEZs are controlled by local investors, the highest proportion among the six African countries studied in the World Bank survey (Farole 2011).

A number of reforms to the SEZ programme need to be undertaken. The most critical is to raise the infrastructure and institutional standards of SEZs to the levels needed to attract regional and global investors. ${ }^{15}$ For example the World Bank survey of SEZs found that firms in Tanzanian SEZs had an average downtime from electricity outages of 50 hours per month. Although this compares favourably with an average downtime of 95 hours per month outside the SEZs, it is not even in the top half of SEZs in Africa. Down times in such popular locations as the Dominican Republic, Bangladesh, and Viet Nam average less than four hours (Farole 2011). A similar pattern occurs in customs clearance. Clearance times in Tanzanian zones are about double that of their African counterparts. Indeed, responses to the survey suggest that the institutional environment inside the zones is actually worse than in the wider national economy. Only 20 per cent of firms in SEZs had access to on-site customs clearance, and clearance times for imports into SEZs (including the stand alone plants) averaged 19 days, compared with 14 days for the economy as a whole.

Reform efforts should focus on raising the performance of geographically concentrated industrial zones. Single factory free zones provide substantial flexibility for investors, but when resources are limited, concentrating them in one location can result in superior service delivery. Geographical concentration also increases the likelihood that firms-and the economy as a whole-will benefit from agglomeration. Recent evidence suggests that that in low-income countries the clustering of closely related firms has the strongest positive impact on firm-level productivity (UNIDO 2009). Production in Tanzania's SEZs is spread across a variety of sectors (mainly in 'other manufacturing') with little evidence of clustering (Farole 2011). To help encourage the formation of clusters of closely related firms, new zones should be located close to suppliers and customers. For example potential zone locations for agribusiness industries should be near the Arusha/Kilimanjaro region due to its high density of farmers, its proximity of domestic and export markets (Kenya), and the existence of a relatively good road network.

Management of the SEZ programme is another critical success factor. The role and responsibilities of the EPZA need to be clarified and its ability to 'get things done' strengthened. Today, in addition to its regulatory role the EPZA also manages the Benjamin William Mkapa SEZ, and its mandate includes developing on-site infrastructure (World Bank 2014a). The

15 Farole (2011) finds that among the African countries surveyed, the top three factors determining investors' decisions to locate in an SEZ were: cost and quality of utilities, access to efficient transport, and the business regulatory environment. 
developer and operator functions of the EPZA should be devolved, ideally to private or publicprivate entities. Its central roles should be promotion and regulation. The current position of the EPZA within government makes it difficult to it to play the coordinating role needed to achieve a 'whole of government' approach to zone development. To attract investment into the zones the EPZA needs to be able to streamline government services (including licensing, registration, utility connections, and fee setting) and resolve disputes. Where zone authorities have played this role effectively they, together with the Investment Promotion Agency, have most often been placed under the Office of the President or the Office of the Prime Minister.

\section{Improving trade logistics}

In Tanzania manufactured export success cannot be separated from the efficiency of trade logistics. Tanzania's emerging exporters tend to specialize in the final stages of the value chain and depend heavily on imported intermediate inputs. Poor trade logistics impact these exporters both through the time and cost of export transactions and perhaps more importantly, through the timeliness and cost of imported intermediates. 'Trade friction costs' resulting from inefficiencies at the port, in domestic transport and in customs and handling can have a significant impact on the cost of imported intermediate inputs, and therefore on a country's attractiveness as a location for task-based exports.

The World Bank has developed a comparative measure of performance in trade logistics, the Logistics Performance Index (LPI). It provides qualitative and quantitative data on the logistics environment in each country, such as information on time and costs in a typical supply chain (World Bank 2014b). There has been little improvement in the LPI for Tanzania since the survey began in 2007. It moved from $137^{\text {th }}$ position in 2007 to $88^{\text {th }}$ position in 2012 but then fell in 2014 to $138^{\text {th }}$ position. In an effort to reduce the variability of year to year changes in the ranking the World Bank (2014b) provides a long-run weighted score using the four waves of LPIs from 2007 through 2014. Except for Burundi, Tanzania under performs other EAC countries in on the LPI. It is ranked at 125 while Uganda is 69, Kenya is 89, and Rwanda at 119. Tanzania is well behind the leading Asian countries such as China, India, Indonesia, Malaysia, and Thailand.

The efficiency of the port of Dar es Salaam is the most acute problem affecting the country's trade logistics. Dar es Salaam is the second largest port in East Africa after Mombasa. However, the port lags substantially behind its regional competitor, in terms of efficiency (Table 7). The main symptoms of the port's inefficiency are long delays at anchorage and in the series of operations needed to remove merchandise from the port, the 'dwell time'. In addition, port tariffs are much higher than in Mombasa. Customs clearance times are high by East African standards and even higher when compared to those of newly industrializing countries elsewhere (Yoshino et al. 2013). The total cost of extra delays and additional monetary payments compared to Mombasa has been estimated to be equivalent to a tariff of 22 per cent on a container imports and of about 5 per cent on bulk imports.

There are currently some promising port reform initiatives underway. A number of technical studies have been conducted and proposed improvements to the port have been advanced by the Tanzania Ports Authority (TPA), the Ministry of Transport, the World Bank, the EU, AfDB, and Trademark EA. The Government's recent 'Big Results Now' initiative on transportation has put improvements to the port of Dar es Salaam at the top of the policy agenda. The proposed reforms have been known for a relatively long time and consist mainly of 'hardware' issues having to do with the infrastructure and layout of the port itself. There is a broad consensus among public and private stakeholders that the reforms are needed, but they have been implemented slowly (Morisset et al. 2012). 
Port reforms worldwide are notoriously hard to implement. Accelerating the pace of reform will require measures to reduce the bargaining power of those who currently benefit from the status quo. Promoting a higher level of competition could reduce the monopolistic power of current port operators and reduce the risk of collusive behaviour. In the short run modifying some existing practices in the port can increase the level of competition. In the longer term competition can be increased by introducing new port operators, including through the privatization of the operating arm of TPA or by privatizing some activities, such as handling operations and maintenance. The use of benchmarks would help in monitoring the performance of port operators and the TPA. A key change would be to clarify the role of the Tanzania Ports Authority. Today, the TPA acts as both the landlord and as one of the two operators in the port. This introduces a major conflict between its roles as operator and regulator (World Bank 2014a).

\subsection{Strengthening the in between sector}

Although the data are sparse, there is some evidence to suggest that Tanzania's new industrial dynamism is mainly the result of the growth of employment in MSEs. A wide range of MSE programmes are in place in Tanzania and are executed by an equally wide range of government institutions, donors, and non-governmental organizations. The rationale for most of these programmes is to contribute to job creation and growth. For example the European Union recently asserted: 'For developing countries, the expansion of the private sector, notably MSMEs is a powerful engine of economic growth and the main source of job creation [emphasis in original]' (EU 2012). This raises two questions: first, are MSEs an appropriate policy target for industrial development, and second, are the programmes currently in place effective? The answer to both questions is likely to be no. Rather than attempting to deal with MSEs as a whole, government should attempt to identify and support the in between sector of micro and small firms with the potential to grow.

MSEs are certainly 'where most of the jobs are' in Tanzania. The household sector generates more than five million such jobs, but the limited data we have from the National Panel Household Survey and the Central Registry of Enterprises suggest that most of those jobs are 'survival' jobs and that most micro and small firms have low productivity, low wages, and high mortality rates. This is consistent with what we know about small enterprises and job creation elsewhere in Africa (Page and Söderbom 2015) and in other economies (Haltiwanger et al. 2010). Generalized programmes of support to micro and small firms are therefore unlikely to be appropriate instruments for creating jobs and boosting economic growth (Page and Söderbom 2015).

There is mounting evidence that traditional MSE programmes may be ineffective. Most of the MSE programmes in Tanzania focus on access to credit and training. After two decades of government and NGO efforts at microfinance programmes, the empirical evidence suggests they are not a panacea. Randomized trials and evidence from the microfinance research literature find that microfinance has failed to achieve the transformative role its advocates foresaw. Take-up rates for credit products are often surprisingly low and not all economic activities that poor people engage in yield high returns. The assumption that breaking financing constraints will boost business startups or allow micro and small business owners to scale-up their operations and grow into larger firms appears only to be true when business owners have the skill and resources to profit from the investment (Banerjee et al. 2010; Bauchet et al. 2011).

The news on training is equally discouraging. McKenzie and Woodruff (2012) provide a critical review of what we are learning from the literature that seeks to evaluate the impact of business training programmes on micro and small firms. Almost all the impact evaluations found that 
participating firms started implementing some-though far from all—of the business practices taught by the training programmes. In fact the extent of change in behaviour in most cases was disappointing. The impacts on performance were small as well, and in in virtually all cases they were not statistically significant. The combination of small changes in business practices and low statistical power meant that few studies found any significant impacts of training on sales or profitability. As in the case of microfinance, training seems to work best when the trainees are entrepreneurs with the capacity to absorb and implement the changes suggested.

One clear implication of the programme evaluations summarized above is that not every owner of a micro or small firm is an entrepreneur. This has led to some recent writing on the importance of 'managerial capital' in economic development (Bruhn et al. 2011), a concept closely linked to that of 'firm capabilities' (Sutton 2012). John Sutton and Donath Olomi (2011) provide a 'map' of Tanzania's firm capabilities in manufacturing. In it they looked at 50 firms in detail to provide a comprehensive picture of Tanzania's industrial capabilities. One of their conclusions is that in Tanzania, as in several other African economies where they had carried out enterprise mapping exercises, there was an absence of business owners capable of managing a well-functioning medium-sized firm. The scarce resource is 'organizational capital' rather than finance (Sutton and Olomi 2011).

This suggests that public policy should be attempting to identify and assist those micro and small firms that are in the right hand tail of the productivity distribution, those with the managerial or organizational capital to grow into well-functioning medium-scale enterprises. One innovative way to support growth of such firms would be to experiment with interventions designed to identify new small firms with the potential for growth. Rather than providing support (such as training or subsidized loans) to a an untargeted group of micro and small firms determined mainly by geographic location and the availability of resources, the government might consider, for example, giving a small grant at start-up to all new firms in the CRE below a certain size.

The grant, which would not be conditional on a credit appraisal, is intended to provide working capital for the startup phase of the firm. The implementing agency would refrain from further interventions designed to improve the 'creditworthiness' or profitability of the enterprise and observe over a period of, say, 2-3 years which firms have been able to survive. It would then use information gathered from the surviving firms to provide support tailored to their needs. At that point the bottleneck to growth might not be finance (after all, the firms have by now had some time to accumulate their own savings). If organizational capital is the constraint, perhaps inadequate skills or lack of marketing and distribution channels will matter more. Such interventions are amenable to randomized experiments, and it should, therefore, be possible to conduct rigorous impact evaluations of the programmes.

\section{Conclusions}

While Tanzania ranks among the leading stars of the African growth miracle its industrial development has not been equal to its recent growth or its national aspirations. Relative to international benchmarks Tanzania suffers from a manufacturing deficit at its current level of per capita income. Perhaps more importantly, relative to Tanzania's ambitious plans to achieve middle-income status, the gap between the role of industry at middle-income levels and the current level of industrial activity is even greater.

The failure to industrialize has some important implications for understanding two of the Tanzanian economies most pressing problems: jobs and poverty. Tanzania has added fewer jobs 
and reduced poverty less than would be expected from its overall growth. 'Jobless growth' and slow poverty reduction are in part a consequence of the slow pace of structural change. Manufacturing, agro-industrial value chains and tradable services are all high-productivity sectors that have the potential to absorb large numbers of modestly skilled workers, contribute to accelerated poverty reduction and diversify the production and export structure. Thus far, despite robust growth they have failed to take off.

In contrast with a number of the other African economies, industry in Tanzania is growing faster than the economy as a whole. Tanzania has had the most rapid growth in manufactured exports among its East African neighbours. This new industrial dynamism appears to come from two sources. First, growth in formal manufacturing has been above the average rate of economic growth, although not as rapid as for some services. Second, a large number of MSEs have entered manufacturing since 2005. These are firms that are not household enterprises but are not 'formal' either. There is some evidence that they are quite heterogeneous and that some have productivity levels that are equal to medium- and large-scale firms. This is the in between sector.

Since the mid-1990s, industrialization has received more attention in Tanzania's national development debate than at any point since the post-independence era, but the results in terms of industrial development have failed to keep pace with the rhetoric. In part this seems to be the consequence of the fact that policy and institutional innovations to boost industrial growth that have been implemented in some other newly industrializing countries have performed less well in Tanzania. This paper dealt with three: SEZs, trade logistics, and MSE programmes. These are areas where decisive government action can increase the prospects for industrial develop across a range of activities from manufacturing to tradable services and agro-industrial value chains.

Many newly industrializing countries have established SEZs as a key component of an exportoriented industrialization strategy. Tanzania has been a relative latecomer to the use of SEZs, and it has not yet raised the infrastructure and institutional standards of its zones to the levels needed to attract regional and global investors. The efficiency of the port of Dar es Salaam is the most acute problem affecting the country's trade logistics and is a major barrier to success in export production. There are currently some promising port reform initiatives underway, but the pace of progress has been slow and must accelerate. Existing MSE programmes may be misdirected, both in terms of the target and the instruments, and should be reformed. A more selective approach aimed at strengthening the in between sector may offer higher returns in terms of jobs and growth.

\section{References}

AfDB (2015). Poverty Database. Data available online at: afdb.org/en/knowledge/statistics/ (accessed on 4 March 2016).

Atkinson, A.B., and M.A. Lugo (2010). 'Growth, poverty and distribution in Tanzania'. Working Paper 10/0831. London: International Growth Centre.

Bauchet, J., C. Marshall, L. Starita, J. Thomas, and A. Yalouris (2011). Latest Findings from Randomized Evaluations of Microfinance. Washington, DC: Consultative Group to Assist the Poor.

Banerjee, A., E. Duflo, R. Glennerster, and C. Kinnan (2010). 'The miracle of microfinance? Evidence from a randomized evaluation'. Cambridge, MA: MIT. 
Bruhn, M., D. Karlan, and A. Schoar (2011). 'What capital is missing in developing countries?'. Cambridge, MA: MIT.

Cadot, O., J. Régolo, and Y. Yoshino (2012). 'Firm-level patterns of export expansion: Evidence from Tanzania'. Washington, DC: World Bank

Chenery, H. (1986). 'Growth and transformation'. In H. Chenery, S. Robinson, and M. Syrquin (eds), Industrialization and Growth: A Comparative Study. New York: Oxford University Press.

de Vries, G., M. Timmer, and K. de Vries (2013).'Structural transformation in Africa: Static gains, dynamic losses'. GGDC Research Memorandum 136. Groingen: Groingen Growth and Development Centre, University of Groingen.

Dinh, H., and C. Monga (2013). Light Manufacturing in Tanzania. Washington, DC: World Bank.

Dinh, H.T., V. Palmade, V. Chandra, and F. Cossar (2012). Light Manufacturing in Africa: Targeted Policies to Enhance Private Investment and Create Jobs. Washington, DC: The International Bank for Reconstruction and Development/World Bank.

EU (2012). 'Accountability Report 2012'. Review of Progress of the EU and its Member States Financing for Development. Brussels: European Union.

Farole, T. (2011). Special Economic Zones in Africa: Comparing Performance and Learning from Experience. Washington, DC: World Bank.

Fosu, A. (2011). 'Growth, inequality, and poverty reduction in developing countries: Recent global evidence'. Centre for the Study of African Economies Working Paper 2011/07. Oxford: CSAE.

Günther, I., and A. Launov (2012). 'Informal employment in developing countries: Opportunity or last resort?. Journal of Development Economics, 97(1):88-98.

Haltiwanger, J., S. Scarpetta, and H. Schweiger (2010). 'Cross country differences in job reallocation: the role of industry, firm size and regulations'. European Bank for Reconstruction and Development Working Papers 116. London: Office of the Chief Economist, European Bank for Reconstruction and Development.

Harrison, A., and A. Rodriguez-Claire (2009). 'Trade foreign investment and industrial policy for developing countries'. NBER Working Paper 15261. Cambridge, MA: NBER.

Hausmann, R., J. Hwang, and D. Rodrik (2006). 'What you export matters'. Journal of Economic Growth, 12: 1-25.

Jones, S., and F. Tarp (2015). 'Priorities for boosting employment in sub-Saharan Africa: Evidence for Mozambique'. African Development Review, 27(S1): 56-70. DOI: 10.1111/14678268.12139.

Kenyon, T., and E. Kapaz (2005). 'The informality trap: Tax evasion, finance and productivity in Brazil'. Public Policy for the Private Sector Note 301. Washington, DC: World Bank.

Kuznets, S. (1955). 'Economic growth and income inequality'. American Economic Review, 45(1): $1-28$.

Kweka, J., and C. Ugarte (2013). 'SMEs at the center stage of competitiveness and job creation: What do we know and need to know for Tanzania?'. Dar es Salaam: World Bank.

Kweka, J., and L. Fox (2011). 'The household enterprise sector in Tanzania: Why it matters and who cares’. Policy Research Working Paper 5882. Washington, DC: World Bank.

Lewis, W.A. (1979) 'The dual economy revisited.' The Manchester School, 47 (3): 211-99. 
McKenzie, D., and C. Woodruff (2012). 'What are we learning from business training and entrepreneurship evaluations around the developing world?'. Policy Research Working Paper 6202. Washington, DC: World Bank.

McMillan, M. (2014). 'Tanzania: Firm capabilities and the "in between" sector'. London: International Growth Sector.

McMillan, M., D. Rodrik, and I. Verduzco-Gallo (2014). 'Globalization, structural change, and productivity growth, with an update on Africa'. World Development, 63:11-32.

Ministry of Industry and Trade (2012). National Baseline Survey Report: Micro, Small and Medium Enterprises in Tanzania. Dar es Salaam: GPO.

Morisset, J., C. Moret, and J. Regolo (2012). 'How to push efficiency enhancing reforms in the port of Dar es Slaam?'. The World Bank Africa Regional Poverty Reduction and Economic Management. Washington, DC: World Bank.

Page, J. (2012). 'Can Africa industrialize?'. Journal of African Economies, 21(suppl 2): ii86-ii124.

Page, J. (2014). 'Structural change and Africa's poverty puzzle'. In H. Kharas and L. Chandy (eds), The Last Mile: Ending Extreme Poverty. Washington, DC: Brookings Press.

Page, J., and A. Shimeles (2015). 'Aid, structural change and poverty reduction in Africa'. Africa Development Review, 27(S1): 17-30.

Page, J., and M. Söderbom (2015). 'Is small beautiful? Small enterprise, aid and employment in Africa'. African Development Review, 27(S1): 44-55. DOI: 10.1111/1467-8268.12138.

Regolo, J. (2012). 'Background technical notes. World Bank Africa region poverty reduction and economic management'. Washington, DC: World Bank.

Rodrik, D. (2013). 'Unconditional convergence in manufacturing'. Quarterly Journal of Economics, 165-204.

Rodrik, D. (2014). 'An African Growth Miracle?'. NBER Working Paper 20188. Cambridge, MA: NBER

Sutton, J. (2012). Competing in Capabilities: The Globalization Process. (Clarendon Lectures in Economics). Oxford: Oxford University Press.

Sutton, J., and D. Olomi (2011). An Enterprise Map of Tanzania. London: International Growth Centre.

van der Ploeg, F. (2011). 'Natural resources: Curse or blessing?'. Journal of Economic Literature, 49(2): $366-420$.

UNIDO (2009). Industrial Development Report, 2009. Geneva: United Nations Industrial Development Organization.

UNIDO (2012). Tanzania Industrial Competitiveness Report 2012. Vienna: United Nations Industrial Development Organization.

UNIDO (2015). Industrial Statistics Database. Available online at: http://www.unido.org/en/resources/statistics/statistical-databases.html (accessed on 4 March 2016).

United Republic of Tanzania (1999). Development Vision 2025. Dar es Salaam: Government Printer.

United Republic of Tanzania (2008). Annual Survey of Industrial Production. Dar es Salaam: Government Printer. 
Wangwe, S., D. Mmari, J. Aikaeli, N. Rutatina, T. Mboghoina, and A. Kinyondo (2014). 'The performance of the manufacturing Sector in Tanzania'. WIDER Working Paper 2014/085. Helsinki: UNU-WIDER.

World Bank (2006). Enterprise Surveys Country Profile Tanzania 2006. Washington, DC: World Bank.

World Bank (2013a). Tanzania's coming Out: The Modernization of the Port of Dar es Salaam (Third Tanzania Economic Update). Dar es Salaam: World Bank.

World Bank (2013b). Tanzania Economic Update: Can Tanzania Eradicate Extreme Poverty?. Dar es Salaam: World Bank.

World Bank (2014a). Productive Jobs Wanted: Tanzania Country Economic Memorandum. Washington, DC: World Bank.

World Bank (2014b). Connecting to Compete. Washington, DC: World Bank.

World Bank (2015a). Export Dynamics Database. Available online at: https://openknowledge.worldbank.org/handle/10986/12070 (accessed on 4 March 2016).

World Bank (2015b). World Development Indicators. Data available online at: http://wdi.worldbank.org/tables (accessed on 4 March 2016).

Yoshino, Y., O. Cadot, F. Ratsimbazafy, and J. Regolo (2013). 'Uncovering drivers for growth and diversification of Tanzania's exports and exporters'. Washington, DC: World Bank. 


\section{Tables}

Table 1: Tanzania structure of output and employment 1960-2010

\begin{tabular}{lcccc|cccc|cccc}
\hline & \multicolumn{5}{c}{ Value added } & \multicolumn{3}{c|}{ Employment } & \multicolumn{3}{c}{$\begin{array}{c}\text { Relative productivity } \\
\text { levels }\end{array}$} \\
\hline & 1960 & 1975 & 1990 & 2010 & 1961 & 1975 & 1990 & 2010 & 1961 & 1975 & 1990 & 2010 \\
\hline Agriculture & $\mathbf{2 6 . 3}$ & $\mathbf{1 7 . 1}$ & $\mathbf{3 1 . 0}$ & $\mathbf{3 0 . 1}$ & $\mathbf{8 9 . 5}$ & $\mathbf{8 9 . 1}$ & $\mathbf{8 6 . 1}$ & $\mathbf{7 3 . 4}$ & $\mathbf{0 . 5}$ & $\mathbf{0 . 4}$ & $\mathbf{0 . 4}$ & $\mathbf{0 . 4}$ \\
Industry & $\mathbf{2 2 . 6}$ & $\mathbf{2 9 . 2}$ & $\mathbf{2 0 . 1}$ & $\mathbf{2 6 . 4}$ & $\mathbf{1 . 4}$ & $\mathbf{2 . 8}$ & $\mathbf{2 . 7}$ & $\mathbf{6 . 0}$ & $\mathbf{1 6 . 0}$ & $\mathbf{8 . 6}$ & $\mathbf{8 . 2}$ & $\mathbf{4 . 4}$ \\
Mining & 3.3 & 0.6 & 0.7 & 3.9 & 0.1 & 0.3 & 0.4 & 0.3 & 35.0 & 3.4 & 1.4 & 10.9 \\
Manufacturing & 14.6 & 22.3 & 10.0 & 10.6 & 1.1 & 1.6 & 1.4 & 2.7 & 8.2 & 7.1 & 5.7 & 3.8 \\
Other industry & 4.7 & 6.3 & 9.3 & 11.9 & 0.2 & 0.9 & 0.8 & 3.0 & 42.1 & 12.9 & 15.7 & 4.3 \\
Services & $\mathbf{5 1 . 2}$ & $\mathbf{5 3 . 7}$ & $\mathbf{4 8 . 9}$ & $\mathbf{4 3 . 6}$ & $\mathbf{9 . 0}$ & $\mathbf{8 . 1}$ & $\mathbf{1 1 . 3}$ & $\mathbf{2 0 . 6}$ & $\mathbf{4 . 0}$ & $\mathbf{5 . 4}$ & $\mathbf{3 . 7}$ & $\mathbf{2 . 1}$ \\
Market services & 30.1 & 30.9 & 32.8 & 29.8 & 1.9 & 4.4 & 6.5 & 12.2 & 13.5 & 6.9 & 4.2 & 2.5 \\
$\quad$ Distribution services & 25.2 & 23.7 & 27.3 & 25.5 & 1.8 & 4.2 & 6.2 & 12.0 & 13.0 & 6.3 & 3.5 & 2.1 \\
$\quad$ Fin. and bus. ser. & 5.0 & 7.2 & 5.5 & 4.3 & 0.1 & 0.2 & 0.2 & 0.2 & 22.3 & 18.0 & 22.1 & 23.4 \\
Non-market services & 21.0 & 22.8 & 16.1 & 13.7 & 7.2 & 3.6 & 4.8 & 8.4 & 1.5 & 3.6 & 3.0 & 1.6 \\
$\quad$ Government services & 16.6 & 18.1 & 14.5 & 13.0 & 4.5 & 2.3 & 3.3 & 6.2 & 2.2 & 5.3 & 4.1 & 2.1 \\
$\quad$ Other services & 4.5 & 4.6 & 1.6 & 0.7 & 2.7 & 1.3 & 1.5 & 2.2 & 0.2 & 0.5 & 0.6 & 0.3 \\
Total economy & $\mathbf{1 0 0}$ & $\mathbf{1 0 0}$ & $\mathbf{1 0 0}$ & $\mathbf{1 0 0}$ & $\mathbf{1 0 0}$ & $\mathbf{1 0 0}$ & $\mathbf{1 0 0}$ & $\mathbf{1 0 0}$ & $\mathbf{1 . 0}$ & $\mathbf{1 . 0}$ & $\mathbf{1 . 0}$ & $\mathbf{1 . 0}$ \\
\hline
\end{tabular}

Notes: Other industry includes construction and public utilities. Distribution includes transport services and distributive trade as well as hotels and restaurants. Finance and business services excludes real estate activities. Other services includes other community, personal and household services. Numbers may not sum due to rounding.

Source: de Vries et al. (2013). 
Table 2: Benchmarking the structure of Tanzania's Economy

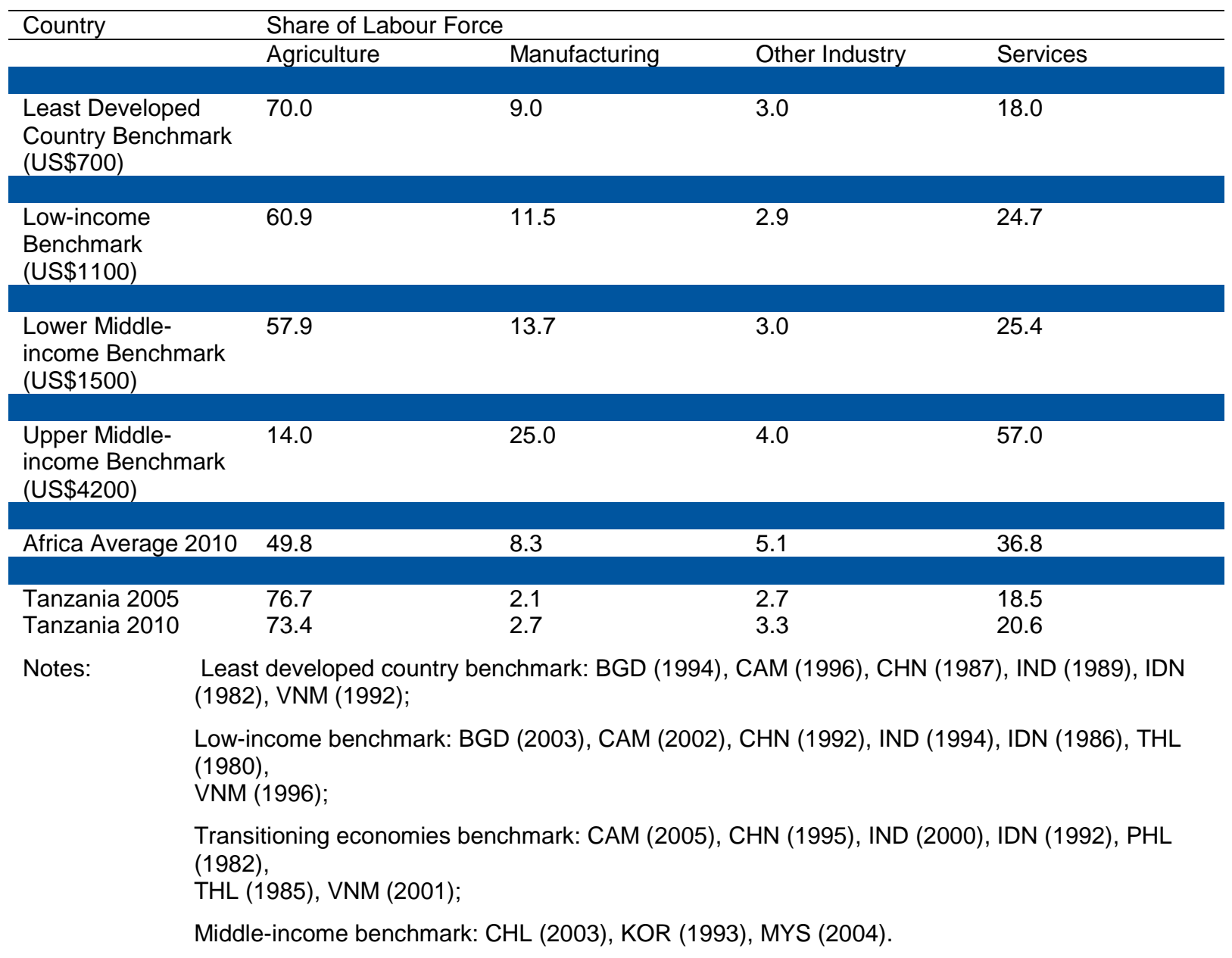

Source: Author's calculations based on World Bank (2015b) World Development Indicators and de Vries et al. (2013). 
Table 3: Poverty headcounts by sector of employment of head of household

\begin{tabular}{llllll}
\hline Country & Year & Overall & Agriculture & Industry & Services \\
\hline Botswana & 2005 & 34.36 & 43.77 & 30.41 & 27.63 \\
Ethiopia & 2005 & 41.56 & 44.31 & 34.98 & 25.16 \\
Ghana & 2005 & 22.60 & 32.58 & 11.51 & 8.22 \\
Malawi & 2011 & 65.60 & 73.78 & 50.74 & 32.05 \\
Mali & 2005 & 47.36 & 53.46 & 45.03 & 33.73 \\
Nigeria & 2010 & 66.80 & 81.64 & 55.44 & 52.80 \\
Rwanda & 2010 & 52.80 & 58.63 & 44.83 & 27.76 \\
Senegal & 2005 & 31.09 & 56.41 & 19.24 & 17.54 \\
South Africa & 2006 & 15.91 & 17.5 & 5.83 & 13.03 \\
Tanzania & 2007 & 62.60 & 70.63 & 29.2 & 37.19 \\
Uganda & 2005 & 36.19 & 43.94 & 26.3 & 14.13 \\
Zambia & 2003 & 64.85 & 70.1 & 62.49 & 47.41 \\
\hline
\end{tabular}

Source: AfDB (2015) Poverty Database; author's calculations. 
Table 4: Structural change and poverty simulations

\begin{tabular}{|c|c|c|c|}
\hline Country & $\begin{array}{l}\text { Observed poverty } \\
\text { headcount }\end{array}$ & $\begin{array}{l}\text { Simulated poverty } \\
\text { headcount }\end{array}$ & $\begin{array}{l}\text { Percentage change in } \\
\text { headcount }\end{array}$ \\
\hline Ethiopia 2005 & 41.6 & 39.7 & -4.6 \\
\hline Malawi 2011 & 65.6 & 63.5 & -3.2 \\
\hline Mali 2005 & 47.4 & 47.4 & 0.0 \\
\hline Rwanda 2005 & 52.8 & 48.5 & -8.1 \\
\hline Tanzania 2007 & 62.6 & 55.2 & -11.8 \\
\hline Uganda 2005 & 36.2 & 34.0 & -6.1 \\
\hline Zambia 2003 & 64.9 & 63.4 & -2.3 \\
\hline Ghana 2005 & 22.6 & 22.9 & 1.3 \\
\hline Nigeria 2010 & 66.8 & 66.6 & -0.0 \\
\hline Senegal 2005 & 31.1 & 40.3 & 29.6 \\
\hline Botswana 2005 & 34.4 & 30.7 & -10.8 \\
\hline South Africa 2006 & 15.9 & 11.6 & -27.0 \\
\hline
\end{tabular}

Source: Author's calculations as described in text. 
Table 5: Selected measures of industrial development, Tanzania 2000-10

\begin{tabular}{|c|c|c|c|c|c|c|c|c|c|c|c|c|c|c|c|}
\hline & \multicolumn{3}{|c|}{$\begin{array}{l}\text { Manufacturing } \\
\text { Value added per } \\
\text { capita } \\
\text { (US\$) }\end{array}$} & \multicolumn{3}{|c|}{$\begin{array}{l}\text { Medium and high } \\
\text { technology share of } \\
\text { manufacturing } \\
\text { production }(\%)\end{array}$} & \multicolumn{3}{|c|}{$\begin{array}{l}\text { Manufactured } \\
\text { exports per capita } \\
\text { (US\$) }\end{array}$} & \multicolumn{3}{|c|}{$\begin{array}{l}\text { Share of } \\
\text { manufactured } \\
\text { exports in total } \\
\text { exports (\%) }\end{array}$} & \multicolumn{3}{|c|}{$\begin{array}{l}\text { Share of medium } \\
\text { and high technology } \\
\text { exports in total } \\
\text { manufactured } \\
\text { exports }(\%)\end{array}$} \\
\hline & 2000 & 2006 & 2010 & 2000 & 2006 & 2010 & 2000 & 2006 & 2010 & 2000 & 2006 & 2010 & 2000 & 2006 & 2010 \\
\hline Tanzania & 18 & 24 & 40 & 12.4 & 12.4 & 12.0 & 7 & 10 & 43 & 37.0 & 26.0 & 42.3 & 3.9 & 11.3 & 16.7 \\
\hline SSA & 28 & 33 & 35 & 7.4 & 14.4 & 15.0 & 23 & 40 & 40 & 25.0 & 24.0 & 24.0 & 8.9 & 18.2 & 20.8 \\
\hline $\begin{array}{l}\text { income } \\
\text { countries }\end{array}$ & -- & 48 & 61 & -- & 20.7 & 20.7 & -- & 83 & 71 & -- & 61.0 & 56.0 & -- & 16.2 & 25.0 \\
\hline
\end{tabular}

Source: UNIDO (2015) Industrial Statistics Data Base. 
Table 6: Export growth decomposition of Tanzania, 2000-10

\begin{tabular}{|c|c|c|c|c|c|c|c|c|}
\hline & \multicolumn{4}{|c|}{ Intensive Margin } & \multicolumn{4}{|c|}{ Extensive Margin } \\
\hline Destination & $\begin{array}{l}\text { Growth in } \\
\text { existing } \\
\text { product to } \\
\text { current } \\
\text { destination }\end{array}$ & $\begin{array}{l}\text { Reduction } \\
\text { in existing } \\
\text { product to } \\
\text { current } \\
\text { destination }\end{array}$ & $\begin{array}{l}\text { Extinction } \\
\text { of existing } \\
\text { product to } \\
\text { current } \\
\text { destination }\end{array}$ & $\begin{array}{c}\text { Total } \\
\text { intensive } \\
\text { margin }\end{array}$ & $\begin{array}{c}\text { New } \\
\text { products in } \\
\text { current } \\
\text { destination }\end{array}$ & $\begin{array}{c}\text { New } \\
\text { destination } \\
\text { of existing } \\
\text { products }\end{array}$ & $\begin{array}{c}\text { New } \\
\text { products to } \\
\text { new } \\
\text { destination }\end{array}$ & $\begin{array}{c}\text { Total } \\
\text { extensive } \\
\text { margin }\end{array}$ \\
\hline \multicolumn{9}{|l|}{ Tanzania } \\
\hline All & $54.7 \%$ & $-6.9 \%$ & $-9.9 \%$ & $37.9 \%$ & $31.1 \%$ & $30.2 \%$ & $0.7 \%$ & $62.1 \%$ \\
\hline Manuf. & $6.9 \%$ & $-2.9 \%$ & $-3.1 \%$ & $1.0 \%$ & $12.6 \%$ & $6.1 \%$ & $0.7 \%$ & $19.4 \%$ \\
\hline Non Manuf. & $47.7 \%$ & $-4.0 \%$ & $-6.9 \%$ & $36.9 \%$ & $18.0 \%$ & $6.4 \%$ & $0.0 \%$ & $24.4 \%$ \\
\hline
\end{tabular}

Source: Regolo (2012).

Table 7: Comparison of port efficiency for containers, Dar es Salaam and Mombasa, May-June 2012

\begin{tabular}{|c|c|c|c|c|c|c|c|c|}
\hline \multicolumn{9}{|c|}{ Containers } \\
\hline \multicolumn{2}{|l|}{ Indicators: } & $\begin{array}{l}\text { Waiting time } \\
\text { at anchorage }\end{array}$ & $\begin{array}{l}\text { Cargo dwell } \\
\text { time }\end{array}$ & $\begin{array}{l}\text { Gross berth } \\
\text { productivity }\end{array}$ & $\begin{array}{l}\text { Cost/price for } \\
\text { shipping } \\
\text { companies }\end{array}$ & $\begin{array}{l}\text { Cost/price for } \\
\text { shippers }\end{array}$ & Total cost & Total cost \\
\hline Unit: & & days & days & $\mathrm{MpH}$ & USD per TEU & USD per TEU & USD per TEU & USD per Ton \\
\hline \multirow{3}{*}{ Dar Es Salaam } & Exports & none & 6 & 14 & 118.2 & 263.0 & 381.2 & 29.9 \\
\hline & Imports & 10 & 10 & 14 & 118.2 & 366.8 & 485.0 & 38.1 \\
\hline & Import transit & 10 & 17 & 14 & 118.2 & 320.0 & 438.2 & 34.4 \\
\hline \multirow{3}{*}{ Mombasa } & Exports & 0 & 4 & 18 & 128.9 & 150.0 & 278.9 & 21.9 \\
\hline & Imports & 0 & 4 & 18 & 128.9 & 150.0 & 278.9 & 21.9 \\
\hline & Import transit & 0 & 9 & 18 & 128.9 & 132.0 & 260.9 & 20.5 \\
\hline
\end{tabular}

Note: These figures have been collected during a field mission in May/June 2012 with the collaboration of the main port operators (TPA and TICTS) and interviews with several port users (see references World Bank 2013a).

Source: World Bank (2013a). 


\section{Figures}

Figure 1 Employment elasticities and growth in Africa

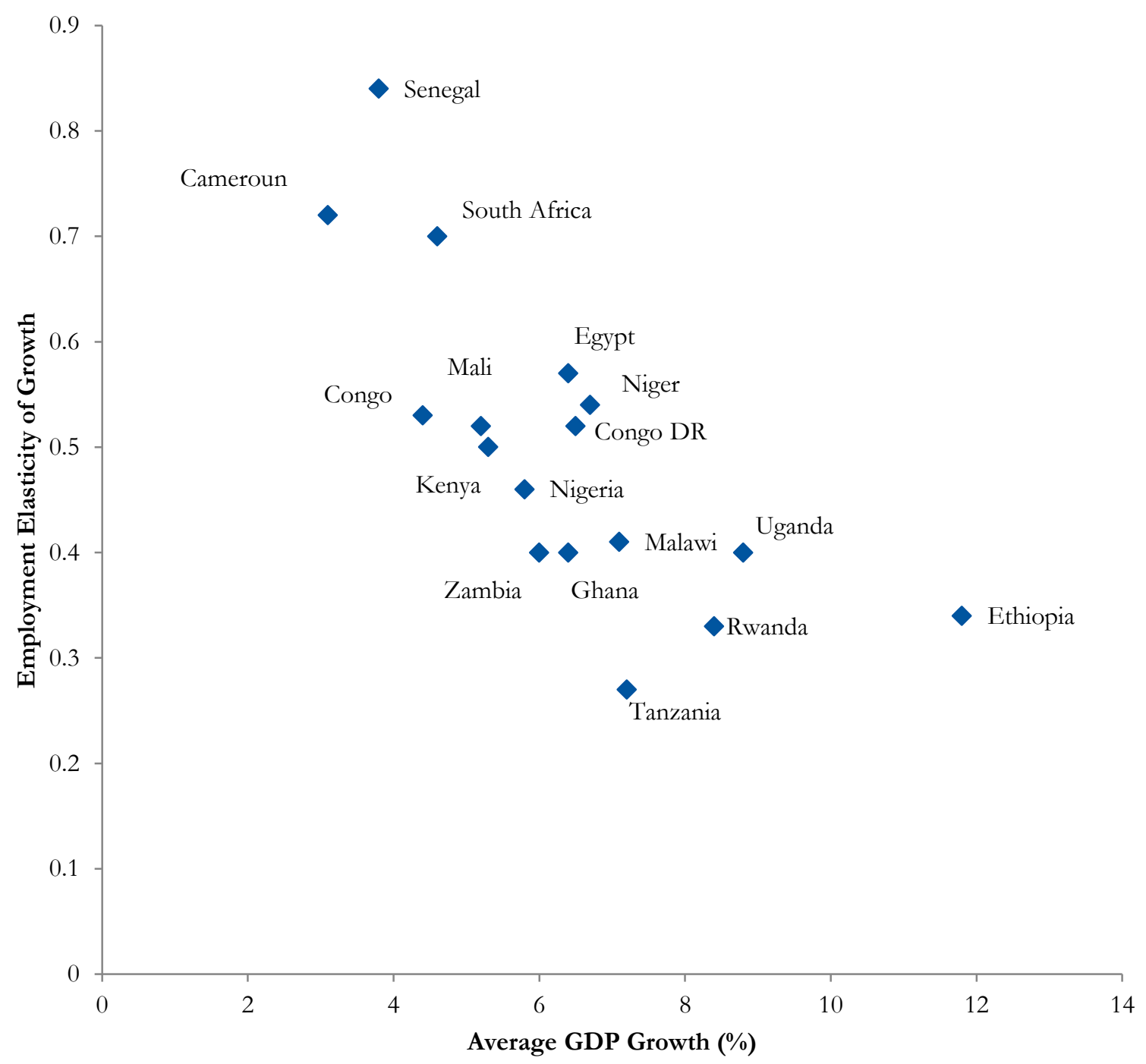

Source: Page and Shimeles (2015). 
Figure 2: Production and export sophistication: Tanzania and fast growing low-income countries

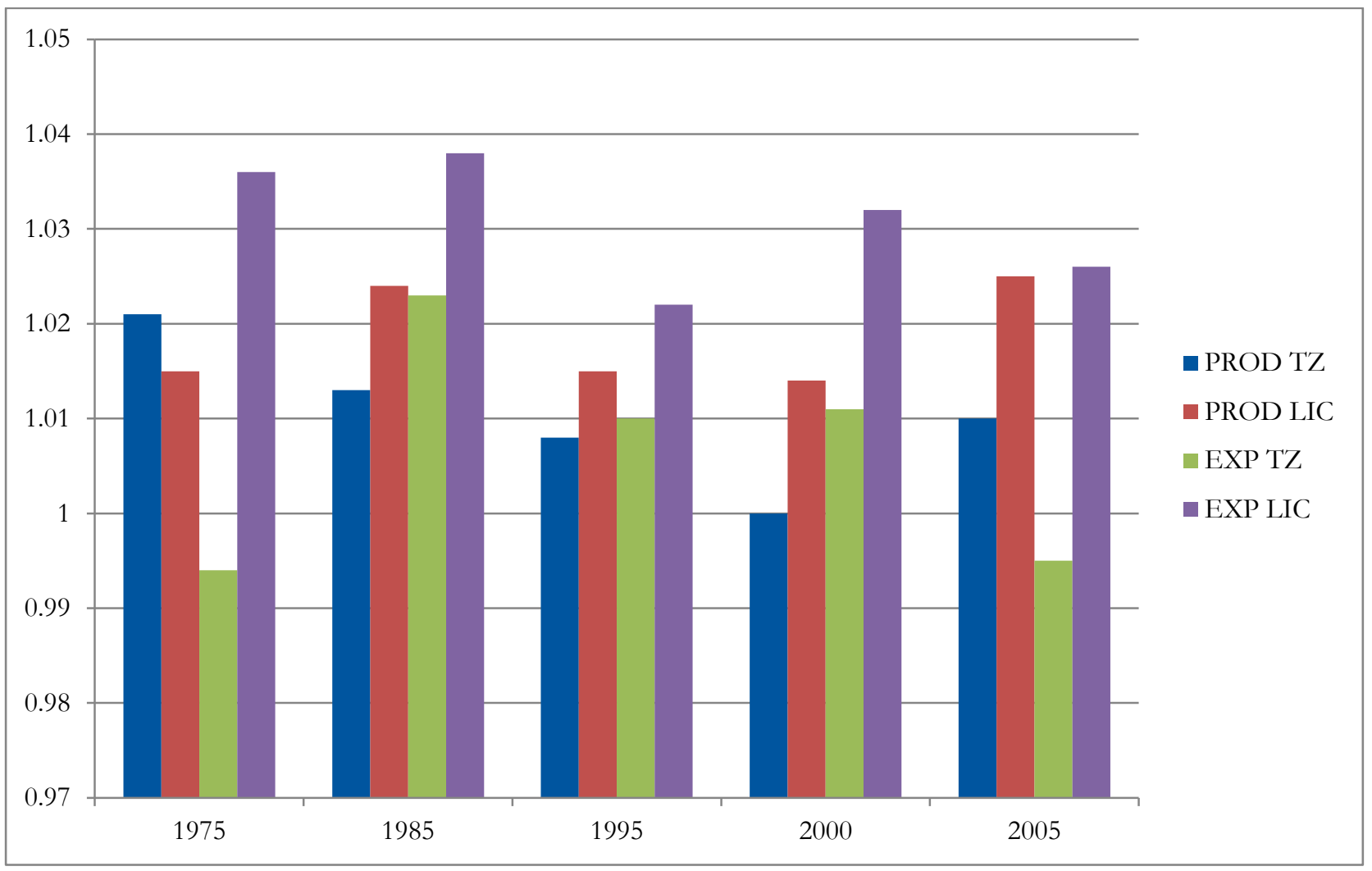

Note: The vertical axis gives the ratio of the observed value to the predicted value of the index of sophistication. Ratios greater than one indicate that the production (export) basket is more sophisticated than predicted from the level of per capita income, and vice versa.

Source: Author's calculations based on UNIDO (2009) Production and Export Sophistication Database. 
Figure 3: Value added per worker and firm size in nine African countries

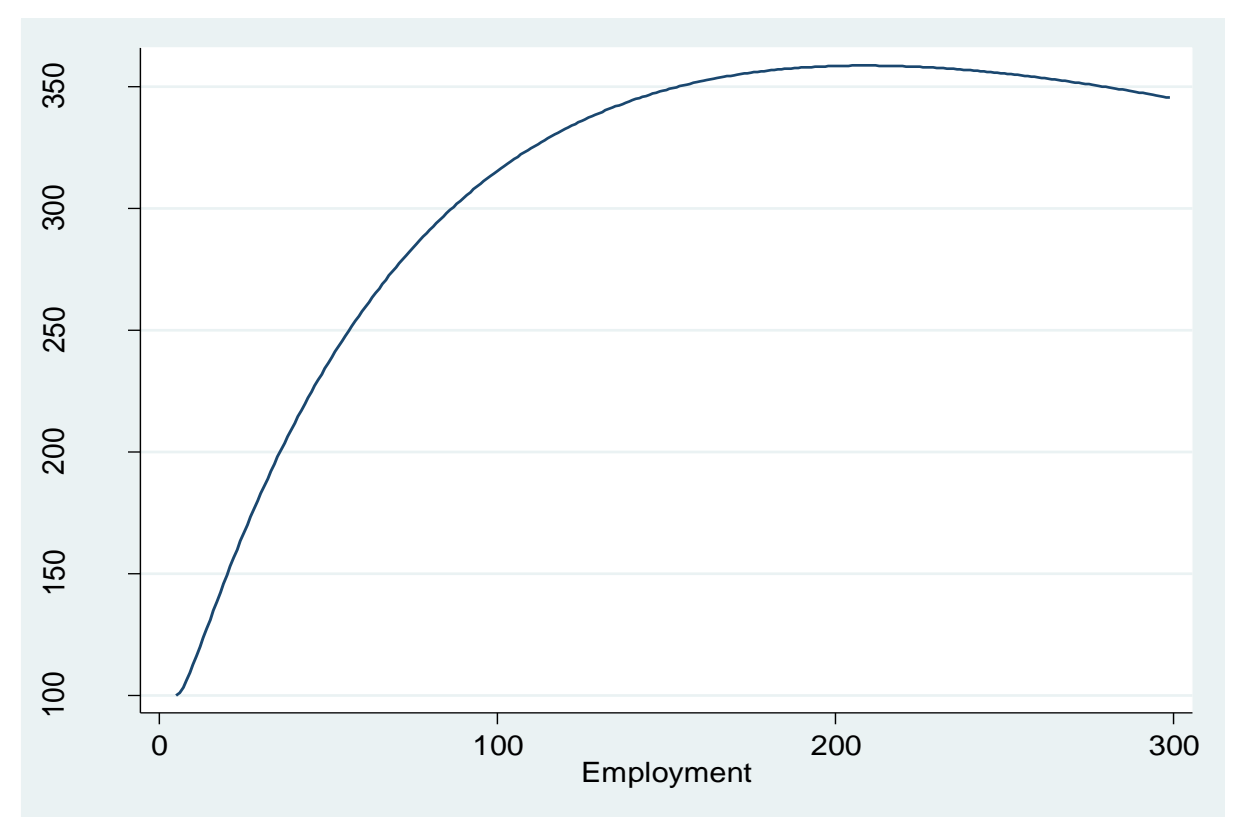

Note: The graph shows predicted value added per worker based on a regression of log value added per worker on a third-order polynomial in log employment and country dummies. The predictions are normalized at 100 for a firm with five employees.

Source: Page and Söderbom (2015).

Figure 4: Distributions of output per worker by firm size, Tanzania 2006

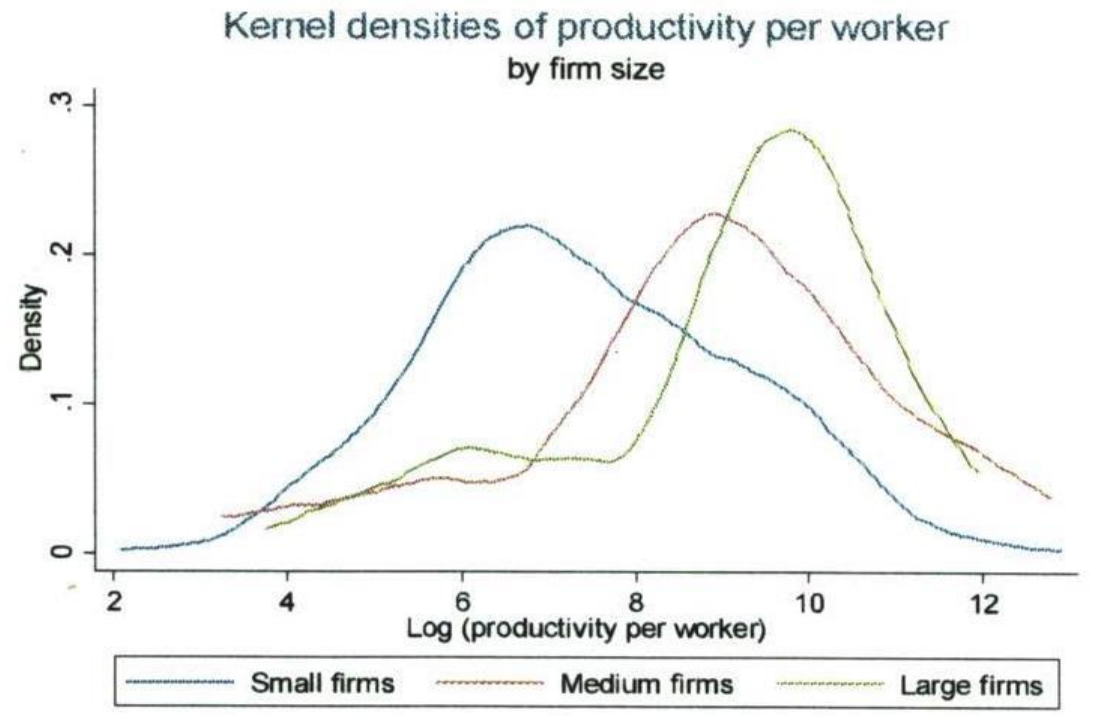

Source: Kweka and Ugarte (2013) calculated from United Republic of Tanzania (2008). 